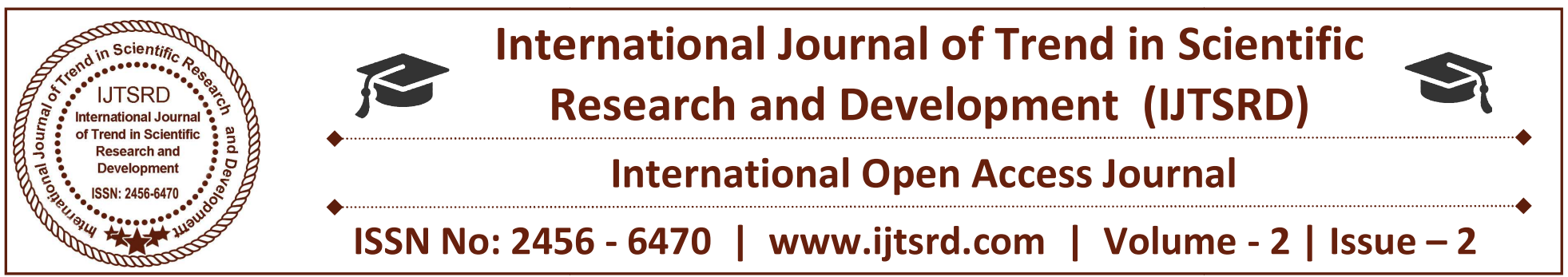

\title{
Role of Demographics on Job Satisfaction of University Teachers in Pakistan
}

\author{
Zermina Tasleem \\ PhD Scholar, Universiti Utara \\ Malaysia Sintok, Malaysia
}

\author{
Sohail Ayaz Muhammad \\ Lecturer, University of Punjab, \\ Lahore, Pakistan
}

\section{ABSTRACT}

The success of any educational sector is based on satisfied and happy teachers. In the today's world, higher education like universities is facing number of challenges while retaining their teachers. University teachers are switching their job very often. The main reason is job dissatisfaction level. As, job satisfaction is a positive feeling of individuals towards their job which make them happy. This study describes the role of demographics such as gender, age, job rank, salary and job status on job satisfaction of private university teachers from Punjab, Pakistan with 273 respondents. The teachers were generally satisfaction with their jobs. Gender and job status showed a positive relationship with job satisfaction. However, age, salary and job rank had negative relationship with job satisfaction of teachers. A significant difference in job satisfaction was found with respect to gender, age, job rank and salary.

Keywords: Job Satisfaction, Demographics, university teachers, Private Universities in Punjab

\section{Introduction}

Role of teachers is absolute in the educational sector as they are producing skilled workers and leaders in every field such as business management, strategic management, human resource management, logistic management, sales and marketing and public management. Focusing on the importance of teachers, the current research attempts to explore the job satisfaction level of private university teachers in
Punjab, Pakistan. According to Pakistan Education Statistics 2015-2016 report, total universities are forty-two in Punjab. Among them, twenty-two are private universities where 5,598 teachers are working. In private universities, teachers are in less ratio as compare to public universities teachers $(11,813)$. However, private universities are high in ratio as compare to public universities. Thus, this research contributes in finding the reasons for less number of teachers in private universities of Punjab and help in improving the universities policies. As, job satisfaction is a vital factor in organizations especially universities and it contributes in the developing, monitoring and improving of different policies related with teachers (Dawal\& Taha 2006).

Numbers of studies are taking job satisfaction as an important point. Job satisfaction level is different for different individuals. Hence, job satisfaction is considered to be a complex notion that is sometimes affected by, and show impacts on the other elements. Job satisfaction defines how much happy and satisfied a person is with his or her job. If the individuals are happy with the job than their job satisfaction level is said to be high (Shukla \&Singh, 2015). Moreover, job satisfaction has an impact on the feeling, attitudes, behaviors and reactions of universities teachers (Strydom, 2011). This inner feeling is considered to be an important instrument for universities and show impact on the performance of teachers.

Job satisfaction is a mixture of positive and negative feeling of teachers related to their job that give 
different feedback at the workplace (Aziri, 2011). Additionally, job satisfaction is an important factor that involve in the formulation of different organizational behaviors (Eslami\&Gharakhani, 2012). There are five factors which become the root of job satisfaction levels. These are salary, job, promotion, colleague and supervision (Khera\& Gulati, 2012). Moreover, there are some main features of job satisfaction at university. These features included responsibility of university in providing proper working facilities and environment to teachers, behaviour of teachers that is based on job satisfaction level which is influenced by different external and internal factors and job satisfaction at university itself that is supposed to be an organizational indicator which improve the performance of teachers (Devi \&Nagini, 2013; Saari\& Judge, 2004).

Furthermore, different theories like Herzberg's motivation-hygiene theory explained the different factors of job satisfaction (Tan \&Waheed,2011). This theory proposed two discrete topics that are satisfaction and dissatisfaction which further based on various factors (Herzberg, 1964). In this theory, the factors that become cause of job satisfaction are known as positive motivators which includes personal development, realization and recognition. These factors recommend few effective opportunities for teachers (Mehrad et al., 2015). Absence of these factors lead towards low satisfaction level. However, it is necessary that job satisfaction should be found in the organization because it is linked with the outcomes of organization (Khalifa \& Troung, 2010). In this theory, there are some external factors like supervision, pay, organizational policies and interpersonal relationships that involves in changing the job satisfaction level. Intrinsic factors are also described in this theory which related with the person self and characteristics (Dhanapal, Alwie, Subramaniam, \&Vashu, 2013). Pay, work environment, security and status are the results of this theory that become cause of job satisfaction (Berghe, 2011). In this research, the factors of this theory play an important role in the job satisfaction of universities teachers.

\section{LITERATURE REVIEW}

Job satisfaction is considered to be a critical issue as it is linked with the outcomes of job such as highperformance level of job, low turnover and organizational citizenship behaviour (Hulin \& Judge,
2003). Job satisfaction is a person feeling and evaluation about job. Job satisfaction is described as assessment of person evaluation level that how the environment of work satisfies their needs (Dawis and Lofquist, 1984). Job satisfaction is a worker feeling towards work and various features of their work (Spector, 1997). Definition of job satisfaction is proposed by Locke (1976) that is a positive and pleasurable state of emotion that is resulted from the assessment of individuals job and their work experiences. Various factors of job satisfaction were explored byPaul and Phua (2011) while studying the level of job satisfaction of faculty in public tertiary institution. Results indicated that job position and age of faculty had impact on the respondent's job satisfaction. While some factors like marital status, academic qualification, employment duration, gender had no significant impact on job satisfaction.

A research made by Sharma and Jyoti (2010) described that job satisfaction of a teachers is a main variable in organizational dynamics and was supposed to be a key dependent factor in evaluating the effectiveness of employees. They viewed extrinsic and intrinsic factors to determine the job satisfaction level of teachers with respect to their age, marital status, gender, level of occupation, academic qualification, employment duration. They explored that some positive factor of job such as sense of accomplishment, creativity, idealness and suitability of job and autonomy had significant impact on job satisfaction of academic staff. However, salary, job condition and co-worker had no significant difference. Patrick (2010) mentioned that job satisfaction level of respondents is dependent on the gender. Females were more satisfied than males. This noted that male workers were not satisfied with the working condition such as salary, benefits etc. It described that male did not have suitably feeling and equitably rewarded with their jobs. Furthermore, participants whose age was 'Below 30' years had high impact on extrinsic factors of job satisfaction and those of age ' $60 \&$ above' years had high impact on intrinsic factors of job satisfaction. However, those of age 40-49 years had lowest score. This indicated that younger faculty are more satisfied than their counterparts. Also, marital status had no relation with job satisfaction. Thus, decision making about the hiring of teachers should be done on other factors instead of marital status.Kainth and Kaur (2010) studied the job satisfaction level of selected teachers from college. 
They found that male college teachers were more satisfied than females.

According to Hesli and Lee (2013), job satisfaction is linked among the faculty from political science department in U.S. They found that faculty who are doing job in private institutions or in high ranked department had higher job satisfaction level. Malik (2011) also studied the job satisfaction level of teachers from University of Balochistan. They resulted that teachers were generally satisfied with their jobs. Female teachers were more satisfied as compare to male. However, some other demographic such as experience, age, rank and qualification had no significant relation with job satisfaction. Shukla \&Singh (2015) found a high job satisfaction level among the faculty in relation to demographics. They studied the association of selected demographics such as gender, family size, age, marital status, educational qualification, experience and rank with job satisfaction. Results showed a significant difference in job satisfaction with respect to selected demographics.

There are many studies which focused on the job satisfaction of faculty members from different universities but very few are exploring the job satisfaction level of teachers from private universities of Punjab, Pakistan. Thus, the aim of this research is to find the job satisfaction level of teachers with respect to selected demographics such as age, gender, job rank, job status and salary from private universities of Punjab. This research had following research questions.

1. What is the job satisfaction level between the teachers from private universities of Punjab?

2. Is there a significance difference among job satisfaction and demographic (gender, age, job rank, salary and job status) of teachers?

Following hypothesis have been tested in this research.

H01: There is no significant difference in the job satisfaction of female and male university teachers.

H02: There is no significant difference in the job satisfaction of university teachers of different age groups.

H03: There is no significant difference in the job satisfaction of university teachers having different job rank.

H04: There is no significant difference in the job satisfaction of university teachers of different salaries.
H05: There is no significant difference in the job satisfaction of university teachers having different job status.

\section{RESEARCH METHODOLOGY}

In this research, quantitative approach is used by focusing on the review of literature. The dependent variable is job satisfaction and independent variable is demographics such as gender, age, job rank, salary and job status. Job satisfaction of university teachers was measured by using seven factors (pay and benefit, involvement in academic process, support and recognition, infrastructure and facilities, teaching and learning, workplace environment and values and work load). For the data collection questionnaire was used. For the reliability and validity, Cronbach's alpha was measured whose value is 0.718 . Hair et al., (2006) stated that the instrument is reliable when Cronbach's alpha value is 0.6 and 0.7 or more (Nunnally, 1978). Thus, the construct of job satisfaction in this research is reliable. A five-point Likert scale was used by reviewing the research of Zaman, Jahan \& Mahmud, 2014.

In this research, population was comprised of teachers from the private universities of Punjab. According to Pakistan Education Statistics 2015-2016, total teachers in private universities of Punjab are 5,598. The sample size for this population is 360 (Krejcie and Morgan, 1970).Simple random sampling methods was used. Thus 360 questionnaires were filled from the teachers of private universities of Punjab. 273 was returned which have 75 percent response rate. Dillman (2000) and Malaney (2002) stated that 30 per cent and 60 per cent response rate are acceptable for the data analysis. Data were analysed through Statistical Package for the Social Sciences (SPSS). Descriptive analysis, Pearson correlation, analysis of variance (ANOVA) and regression was computed to find the results for this research.

\section{Results}

Data was selected from 273 universities teachers working in private universities of Punjab, Pakistan. Out of 273 teachers, $53.1 \%$ were male and remaining $46.2 \%$ of females. The participants consisted of $29.3 \%$ were below 30 years, $63.7 \%$ were from $30-40$ years old and rest of $7 \%$ were above 40 years. In terms of job status, $28.6 \%$ were permanent and $55.7 \%$ were contractual. The $31.9 \%$ teachers had salary less than $30,000,35.9 \%$ had 30,000 to 60,000 , $10.6 \%$ had 60,001 to 90,000 and $1.8 \%$ had 90,001 and 
above. Lecturers were $62.3 \%$, assistant professors were $11.0 \%$ and associate professor were $24.5 \%$.

The results also showed that the universities teachers were generally satisfied with their job $(M=2.73, S D$ $=0.70)$. This result supported the researches of Syed et al., (2012), Malik (2011), Noordin and Jusoff (2009) and Castillo \& Cano (2004). To test the hypothesis Pearson correlation, ANOVA and regression was used and computed values of these test are shown in Table 1 and 2. Gender $(\mathrm{M}=1.47, \mathrm{SD}=$ .514) showed a positive correlation with job satisfaction $(\mathrm{R}=.235, \mathrm{P}=.000)$. Also, male and female universities teachers are significantly difference in terms of their job satisfaction level $(\mathrm{F}=$ $7.95, \mathrm{P}=.000)$. It rejected the $\mathrm{H} 01$. These results are in line with the researches of Callister (2006) and Malik(2011) but not same with Hesli and Lee (2013).

Regarding age $(\mathrm{M}=2.12, \mathrm{SD}=.916)$ of teachers, results showed a negative relationship with job satisfaction $(\mathrm{R}=-.139, \mathrm{P}=.012)$ and significant different found among job satisfaction level of teachers of different ages $(\mathrm{F}=14.1, \mathrm{P}=.000)$. This result also rejected the $\mathrm{H} 02$ and it supported the Malik
(2011), Ghafoor (2012). The job rank $(\mathrm{M}=2.13, \mathrm{SD}=$ 1.68) of respondents showed a negative correlation with job satisfaction level of teacher $(\mathrm{R}=-.312, \mathrm{P}=$ $.000)$ and significant difference was found among Lecturers, assistant professorsand associate professor $(\mathrm{F}=19.8, \mathrm{P}=.000)$. H03 is rejected.These results in line with the studies of Ghafoor (2012), Malik (2011), Wong and Heng (2009), Ssesanga and Garrett (2005).

The respondents were classified on different salary groups $(\mathrm{M}=2.41, \mathrm{SD}=1.50)$ and results indicated a negative correlation of salary with job satisfaction ( $R$ $=-.116, \mathrm{P}=.028)$. There is a significant difference in the level of job satisfaction with different salary groups $(\mathrm{F}=9.23, \mathrm{P}=.000)$. Results rejected the $\mathrm{H} 04$. Job status $(\mathrm{M}=1.88, \mathrm{SD}=.700)$ showed a positive relationship with job satisfaction of teachers $(\mathrm{R}=$ $.145, \mathrm{P}=.008)$. There is no significant difference found in terms of job satisfaction and job status of university teachers $(\mathrm{F}=2.05, \mathrm{P}=.107)$. This accepted the $\mathrm{H} 05$.

\section{Table 1: Results of Pearson correlation and ANOVA}

\begin{tabular}{|l|l|l|l|l|l|l|}
\hline $\begin{array}{l}\text { Demographic } \\
\text { factors }\end{array}$ & Mean & $\begin{array}{l}\text { Std. } \\
\text { Deviation }\end{array}$ & $\begin{array}{l}\text { Pearson } \\
\text { correlation }\end{array}$ & Sig. & F & Sig. \\
\hline Gender & 1.47 & .514 & $.2350=04 / 0$ & .000 & 7.95 & .000 \\
\hline Age & 2.12 & .916 & -.139 & .012 & 14.1 & .000 \\
\hline Job rank & 2.13 & 1.68 & -.312 & .000 & 19.7 & .000 \\
\hline Salary & 2.41 & 1.45 & -.116 & .028 & 9.23 & .000 \\
\hline Job status & 1.88 & .700 & .145 & .008 & 2.05 & .107 \\
\hline
\end{tabular}

Note. The mean difference is significant at the $p<.05$

Table 2 showed the results of regression analysis. Additionally, significant adjusted $\mathrm{R}^{2}$ represented that gender, age, job rank, salary and job status respectively have $17.0 \%, 18.8 \%, 9.4 \%, 22.0 \%, 20.0 \%$ of the variance on job satisfaction. More, standardized coefficient " $\beta$ " and T values were also significant $(p<0.005)$.

Table 2: Regression Analysis

\begin{tabular}{|l|l|l|l|l|}
\hline $\begin{array}{l}\text { Demographic } \\
\text { factors }\end{array}$ & Adj.R & R & T & Sig. \\
\hline Gender & .170 & .249 & 4.32 & .000 \\
\hline Age & .188 & -.248 & -4.08 & .000 \\
\hline Job rank & .094 & -.266 & -4.83 & .003 \\
\hline Salary & .220 & -.117 & -3.08 & .002 \\
\hline Job status & .200 & .208 & 3.75 & .000 \\
\hline
\end{tabular}




\section{CONCLUSION}

It was concluded that job satisfaction of teachers plays a significant role in attaining high teaching standards and quality of education. Finding of this study revealed that teachers of private universities of Punjab were generally satisfied with their job. On the basis of demographics there is a positive relationship of job satisfaction with gender and job status. However, age, job rank and salary showed a negative relationship with job satisfaction. Job satisfaction of teachers indicated significant difference in the perspective of gender, age, job rank and salary groups but there is no significant difference found in job satisfaction of teachers based on job status. Moreover, the analysis of teachers with demographics contributes in re-examine the present organizational policies. It is helpful for management of universities and policy makers to improve the job satisfaction level of teachers and employees. They have to take more interest in the identification and enhancement of different factors which increase the job satisfaction level.

\section{REFERENCES}

1. Aziri, B. (2011). Job satisfaction: A literature review. Management Research \& Practice, 3(4).

2. Berghe, V., \& Hyung, J. (2011). Job satisfaction and job performance at the work place.

3. Callister, R. R. (2006). The impact of gender and department climate on job satisfaction and intentions to quit for faculty in science and engineering fields. Journal of Technology Transfer, 31, 367-375.

4. Cano, J., \& Castillo, J. X. (2004). Factors explaining job satisfaction among faculty. Journal of Agricultural Education, 45(3), 65-74.

5. Dawal, S. Z. M., \& Taha, Z. (2006). The effect of job and environmental factors on job satisfaction in automotive industries. International Journal of Occupational Safety and Ergonomics, 12(3), 267280.

6. Dawis, R. V., \&Lofquist, L. H. (1984). A psychological theory of work adjustment: An individual-differences model and its applications. University of Minnesota Press.

7. Devi, V. R., \&Nagini, A. (2013). An Investigation of Factors influencing job satisfaction of employees in banking sector of india. International Journals of Research in
Organizational Behaviour and Human Resource Management, 1(3), 107-115.

8. Dhanapal, S., Subramaniam, T., \&Vashu, D. (2013). Factors affecting job satisfaction among academicians: A comparative study between gender and generations. International Journal of Management Excellence, 2(1), 128-139.

9. Dillman, D. A. (2000). Mail and internet surveys: The tailored design method. New York: John Wiley and Son.

10. Eslami, J., \&Gharakhani, D. (2012). Organizational commitment and job satisfaction. ARPN Journal of Science and Technology, 2(2), 85-91.

11. Ghafoor, M. M. (2012). Role of demographic characteristics on job satisfaction. Far East Research Centre, 6(1), 30-45.

12. Hair, J. F., Anderson, R. E., Tatham, R. L., \& Black, W. C. (2006). Multivariate data analysis 6th edition prentice hall. New Jersey.

13. Herzberg, F. (1964). The motivation-hygiene concept and problems of manpower. Personnel Administration.

14. Hesli, V. L., \& Lee, J. M. (2013). Job Satisfaction in Academia: Why Are Some Faculty Members Happier Than Others?. PS: Political Science \& Politics, 46(2), 339-354.

15. Hulin, C. L., \& Judge, T. A. (2003). Job attitudes. Handbook of psychology.

16. Kainth, G. S., \& Kaur, G. (2011). Job satisfaction: A challenging area of research in education.

17. Khalifa, M. H. E. D., \& Truong, Q. (2010). The relationship between employee perceptions of equity and job satisfaction in the Egyptian private universities. Eurasian Journal of Business and Economics, 3(5), 135-150.

18. Khera, S. N., \& Gulati, K. (2012). Job satisfaction: A ray of sunshine even in burnout times: Perceptual analysis of IT organizations. International Journal of Management \& Information Technology, l(3), 111-117.

19. Krejcie, R. V., \& Morgan, D. W. (1970). Determining sample size for research activities. Educational and psychological measurement, 30(3), 607-610. 
International Journal of Trend in Scientific Research and Development (IJTSRD) ISSN: 2456-6470

20. Locke, E. A. (1976). The nature and causes of job satisfaction. Handbook of industrial and organizational psychology.

21. Malaney, G. D. (2002). You still need high response rates with web-based surveys. Student Affairs On-Line, 3(1).

22. Malik, N. (2011). STUDY ON JOB SATISFACTION FACTORS OF FACULTY MEMBERS AT UNIVERSITY OF BALOCHISTAN. International Journal of Academic Research, 3(1).

23. Mehrad, A., Hamsan, H. H. B., Redzuan, M. R., \& Abdullah, H. (2015). The role of job satisfaction among academic staff at university. Proceeding of the 3rd Global Summit on Education GSE, 9-10.

24. Noordin, F., \&Jusoff, K. (2009). Levels of job satisfaction amongst Malaysian academic staff. Asian Social Science, 5(5), 122.

25. Nunnally, J. C., \& Bernstein, I. (1978). Psychometric theory. New York: MacGraw-Hill.

26. Patrick, H. A. (2010). Personality traits in relation to job satisfaction of management educators.

27. Paul, E. P., \&Phua, S. K. (2011). Lecturers' job satisfaction in a public tertiary institution in Singapore: ambivalent and non-ambivalent relationships between job satisfaction and demographic variables. Journal of Higher Education Policy and Management, 33(2), 141151.

28. Saari, L. M., \& Judge, T. A. (2004). Employee attitudes and job satisfaction. Human resource management, 43(4), 395-407.

29. Sharma, R. D., \& Jyoti, J. (2009). Job satisfaction of university teachers: An empirical study. Journal of Services Research, 9(2), 51.

30. Shukla, S. \&Singh, S. (2015). Faculty Job Satisfaction: Influencing Role of Demographic Variables. Indian Journal of Educational Studies, 2(1), 39-45.

31. Spector, P. E. (1997). Job satisfaction: Application, assessment, causes, and consequences (Vol. 3). Sage publications.

32. Sseganga， K., \& Garrett, R. M. (2005). Job satisfaction of university academics: Perspectives from Uganda. Higher Education, 50, 33-56.

33. Strydom, A. (2011). The job satisfaction of academic staff members on fixed-term employment contracts at South African higher education institutions (Doctoral dissertation, University of the Free State).

34. Syed, A. A. S. G., Bhatti, N., Michael, S., Shaikh, F. M., \& Shah, H. (2012). Job satisfaction of faculty members of universities in Pakistan: A case study of university of SindhJamshoro. Modern Applied Science, 6(7), 89.

35. Tan, T. H., \&Waheed, A. (2011). Herzberg's motivation-hygiene theory and job satisfaction in the Malaysian retail sector: The mediating effect of love of money.

36. Wong, E. S. K., \&Heng, T. N. (2009). Case study of factors influencing job satisfaction in two Malaysian universities. International Business Research, 2(2), 86-98.

37. Zaman, S., Jahan, A., \& Mahmud, M. d. A. L. (2014). Job Satisfaction of University Teacher's: A Study on Private University in Bangladesh. European Journal of Business and Management, 6(31), 138-147. 